\title{
Core educational components of interprofessional education in pediatric emergencies: An integrated review
}

\author{
Soonyoung Shon ${ }^{1}$, Hyejin Jeon ${ }^{2}$, Heejin Hwang ${ }^{3}$ \\ ${ }^{1}$ Assistant Professor, College of Nursing, Keimyung University, Daegu; ${ }^{2}$ Graduate Student, College of Nursing Science, Kyung Hee University, Seoul; ${ }^{3}$ Doctoral \\ Candidate, College of Nursing Science, Kyung Hee University, Seoul, Korea
}

Purpose: This study was conducted to explore the core educational components of interprofessional education (IPE) for pediatric emergencies to establish a basis for interprofessional simulation education. Methods: Using Whittemore and Knafl's integrative review method, we searched for studies in PubMed, Embase, Cochrane Library, CINAHL, and four South Korean databases (RISS, NDSL, DBpia, and KISS). Results: We identified 21 studies on the general characteristics of IPE in pediatric emergency situations and integrated the core components of IPE according to a PRISMA flowchart. Three core components were identified (individual-competent professionals, team-cooperative professions, and outcome-optimal achievement), with the subthemes of role and responsibility, clinical judgment, performance, leadership, communication, teamwork, patient safety, and quality improvement. Conclusion: We recommend that IPE pediatric emergencies should contain the three dimensions of these core components to enhance individual and team performance and to promote optimal achievement in terms of patient outcomes. IPE programs should consider these characteristics and include a valid tool for evaluating the programs' effectiveness.

Key words: Interprofessional education; Pediatric emergency medicine; Simulation training

\section{Corresponding author} Soonyoung Shon College of Nursing, Keimyung University, 1095 Dalgubeol-daero, Dalseo-gu, Daegu 42601 Korea

TEL: +82-53-258-7651

FAX: $+82-53-258-7616$

E-MAIL: sy.shon@kmu.ac.kr

Received Feb 28, 2021

Revised Mar 22, 2021

Accepted Apr 8, 2021

\section{INTRODUCTION}

Clinical practicum programs for students in nursing and medicine involve direct experience in caring for patients in diverse and complex medical environments; however, the rapid development of clinical environments and the increasing awareness of patient safety and rights have reduced students' practice opportunities in the clinical field [1]. In response to these factors, clinical practicum programs in healthcare professions are continually changing. As it becomes difficult to practice with real patients, simulation education using low-fidelity and high-fidelity simulators and practical education using virtual reality simulations are being proposed; many studies have implemented these proposed training methods and evaluated their effects [2]. In particular, scenarios have been developed involving simulations and practice cases regarding the treatment or care of patients in circumstances that are difficult to experience first-hand in the clinical field, such as patients in severe conditions, those with rare diseases, and newborns/toddlers [3]. These changes reflect the evolving educational environment and aim to enable nurses, physicians, pharmacists, and healthcare professionals entering the clinical environment to adapt immediately to real-world clinical settings. However, in the clinical field, each professional group has its own role, and collaboration between professional groups is necessary. As it has been established that teamwork, communication, and cooperation play an important role in patient outcomes, the need for interprofessional education (IPE) has emerged, and in many countries IPE starts from the undergraduate level [4]. IPE is a process in which two or more experts learn together, learn from each other, and learn about each other [5]. Reports have indicated that IPE is safe and effective for teaching basic skills and knowledge, and improves communication among professional groups [6]; thus, IPE can ultimately lead to improved patient safety and patient outcomes [7]. 
Researchers have reported that special training is needed for pediatric emergencies, even among clinicians with emergency department training. Because emergencies involving children are especially difficult to predict and are characterized by rapid changes in status, collaboration and communication among medical staff are particularly important. New nurses, interns/residents, and other healthcare professionals entering clinical practice often express difficulties in adapting to the pediatric clinical field [8]. A primary factor related to this problem in transition is reportedly the "inadequate ability to cope with emergency situations" [9]. Rosenstein and Naylor [10] demonstrated that effective communication between professional groups in emergency situations affected the treatment outcomes of patients. Therefore, effective IPE strategies for pediatric emergencies are needed. However, research on systematic methods for delivering effective IPE has not been conducted.

This study aimed to identify the core components of IPE for pediatric emergency situations through an integrated review to provide a basis for IPE in this context.

\section{METHODS}

Ethics statement: This study is a literature review of previously published studies and was therefore exempt from institutional review board approval.

This integrated review was intended to analyze the performance and results of IPE for pediatric emergencies. Based on the integrated review methodology of Whittemore and Knafl [11], we aimed to enhance our understanding of effective IPE methods by combining and integrating the results of a wide range of literature related to the research purposes. Within this framework, the review was done in five stages: problem identification, literature search, data evaluation, data analysis, and presentation. The literature search was conducted in accordance with the Preferred Reporting Items for Systematic Reviews and Meta-Analyses (PRISMA) statement by the Cochrane Collaboration. Three researchers independently completed the quality assessment checklist. In cases of disagreement regarding the quality evaluation, a consensus was reached among all researchers after sufficient discussion.

\section{Problem Identification}

The problem identification stage included problem recognition: clearly recognizing the phenomenon that the researcher wants to consider (the problem to be solved) and the purpose of the study. The research problem in this study was "What are the core components for IPE in pediatric emergencies?" In this study, IPE in child emergencies was defined as "education in response to emergencies for two or more professions providing child healthcare."

\section{Literature Search}

The literature search strategy was developed through consultation with a librarian at the institution to which the authors belong. The literature search was performed between June and July 2020 using four international databases (PubMed, Embase, Cochrane Library, and CINAHL) and four South Korean databases (RISS, NDSL, DBpia, and KISS). The search of the Korean databases yielded 10 studies, all of which were found to be irrelevant and were excluded. Other eligible studies were identified by manual searching on Google Scholar. Boolean search techniques were utilized using keywords and medical subject headings (MeSH) terms: ("pediatric" OR "child" OR "birth" OR "newborn" OR "infant" OR "toddler" OR "elementary school student") AND ("emergency situation" OR "emergency" OR "emergencies" OR "hospital emergency") AND ("interprofessional" OR "inter-professional") AND ("education" OR "learning" OR "course" OR "collaboration" OR "simulation" OR "teamwork" OR "curriculum" OR "training" OR "approach" OR "program" OR "practice" OR "care" OR "relations").

\section{Inclusion and Exclusion Criteria}

The inclusion criteria were as follows: studies that 1) conducted education on pediatric medical emergency situations; 2) described the provision of IPE for professionals or students from two or more different professional backgrounds; 3 ) evaluated the learning outcomes of IPE; 4) were peer-reviewed; 5) were published in English; and 6) were published after 2010. The search range of 2010-2020 was chosen in light of the fact that Buring and colleagues [12] introduced IPE definitions, student competencies, and implementation guidelines in 2009 and the Interprofessional Education Collaborative (IPEC) introduced the IPE core competency in 2011.

\section{Data Evaluation}

The Mixed Methods Appraisal Tool [13] was applied for a critical quality appraisal of the analyzed studies. This tool was developed to evaluate the quality of quantitative, qualitative, and mixed-method studies. The assessed results led to an overall score for five methodological quality criteria, ranging from low quality (0 to 3 ) to high quality (4 to 5 ). All authors evaluated the studies independently, and then shared the results. Any disagreements were resolved through discussion. 


\section{Data Analysis and Presentation}

To describe the study characteristics, information was extracted on study design, participants, assessment methods, and assessment tools, as well as the educational content of IPE for pediatric emergencies (pediatric patient age, teaching strategy, and simulation structure). All authors read the papers included in the review individually and analyzed the key educational concepts of each IPE program. Through discussion, the authors aggregated, compared, and contrasted the content of the analysis and identified repeatedly presented patterns of educational components. Themes and subthemes for educational components were selected, and the adequacy and inclusiveness were verified. Based on the themes and subthemes, the educational components of IPE used in each study were reaffirmed and integrated conclusions were presented.

\section{RESULTS}

\section{Study Selection}

Following the initial search, 434 studies were identified via the databases (PubMed=190, Embase=107, Cochrane Library $=20$, and CINAHL $=109$ ) and academic search engine (Google Scholar=8); 292 studies remained after excluding duplicates. After reviewing titles and abstracts, the full texts of 145 studies were assessed. Among them, 21 studies met the inclusion criteria, while 124 articles were excluded. Of the 124 excluded studies, 22 did not deal with pediatric emergency situations; 68 did not describe IPE; three were not written in English; 29 were not original articles; and two were written before 2010 (Figure 1).

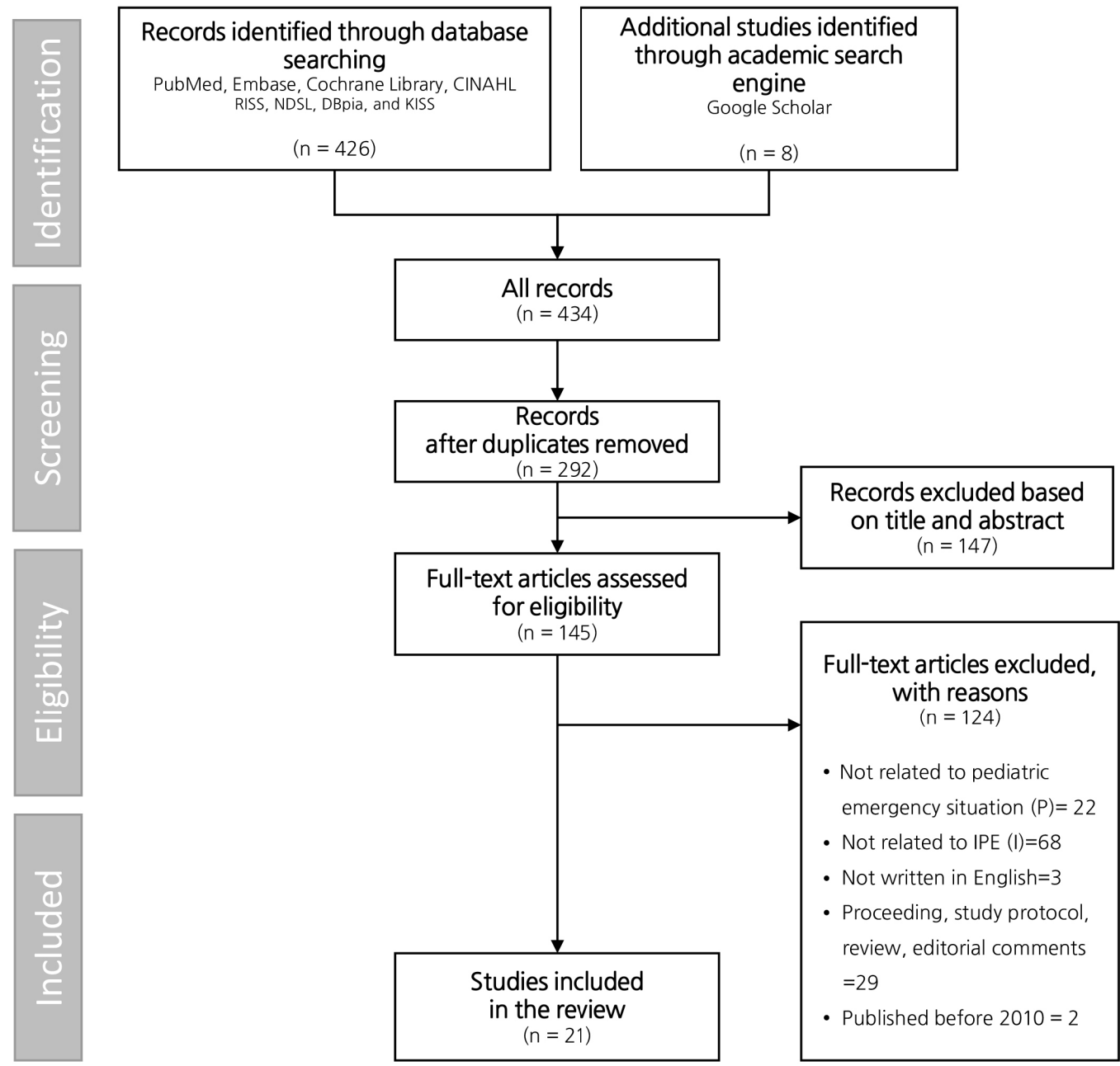

Figure 1. PRISMA flow chart for literature selection. I, interventions; IPE, interprofessional education; $P$, participant. 


\section{Quality Appraisal}

The final 21 selected papers included 15 quantitative studies (non-randomized studies), five mixed-method studies, and 1 qualitative study. In the evaluation according to the criteria of each study method, 15 studies were rated as being of high quality ( 13 studies $=5$ points, 2 studies $=4$ points), while the remaining six studies were assessed as either ineligible based on the screening questions or of low quality. The authors focused on the educational components considered when performing IPE for pediatric emergencies in papers suitable for integration. Based on a discussion, given the aims of the present study, we thought that it was more important to identify what the researchers of each study hoped to gain from IPE than whether the processes of the studies were rigorous. Therefore, we decided that including all relevant studies, even if their quality appraisal score did not meet the criteria, would produce more valuable results in terms of the analysis and integration of IPE content.

\section{Characteristics of the Studies}

Table 1 shows the characteristics of the 21 studies published in or after 2010 that were included in this review. Among the 15 that used a quantitative design, there were nine pretest- posttest studies, one retrospective study, two cohort studies, and three observational studies. Each study included two to four types of professionals (e.g., nurses, physicians, technicians, and others). Examples of "others" include social workers, behavioral health workers, and law enforcement officers. Most of the studies used surveys as assessment instruments to measure attitudes, perceptions, and satisfaction; other methods included interview/focus groups, skill performance ratings, and equipment checklists. In the quantitative studies, various instruments were used to measure IPE outcomes, of which the most prevalent were the Pediatric Readiness Survey (PRS) and Simulation Team Assessment Tool (STAT). Other IPE measurements included the Team Strategies and Tools to Enhance Performance and Patient Safety (TeamSTEPPS), Team Emer-

Table 1. Characteristics of the Studies $(N=21)$

\begin{tabular}{|c|c|c|c|}
\hline Variables & & Categories & $\mathrm{n}(\%)$ \\
\hline \multirow[t]{6}{*}{ Study design } & \multirow[t]{4}{*}{ Quantitative } & Pretest-posttest & $9(42.8)$ \\
\hline & & Retrospective study & $1(4.8)$ \\
\hline & & Cohort & $2(9.5)$ \\
\hline & & Observation & $3(14.3)$ \\
\hline & \multirow[t]{2}{*}{ Mixed qualitative } & Mixed method & $5(23.8)$ \\
\hline & & Grounded theory & $1(4.8)$ \\
\hline \multirow[t]{8}{*}{ Participants } & \multirow[t]{3}{*}{2 Professions } & Nurses+physicians & $3(14.3)$ \\
\hline & & Nurses+others* & $1(4.8)$ \\
\hline & & Physician+others* & $1(4.8)$ \\
\hline & \multirow[t]{3}{*}{3 Professions } & Nurses+physicians+technicians & $9(42.8)$ \\
\hline & & Nurses+physicians+others* & $2(9.5)$ \\
\hline & & Nurses+technicians+others* & $2(9.5)$ \\
\hline & \multirow[t]{2}{*}{4 Professions } & Nurses+physicians+technicians+others* & $2(9.5)$ \\
\hline & & Nurses+physicians+PAs+others* & $1(4.8)$ \\
\hline \multirow[t]{4}{*}{ Assessment methods ${ }^{\dagger}$} & & Attitude/perception/satisfaction survey & 29 \\
\hline & & Interview/focus group & 3 \\
\hline & & Skill performance rating & 3 \\
\hline & & Others (equipment) & 2 \\
\hline \multirow[t]{8}{*}{ Assessment tools ${ }^{\dagger}$} & & PRS & 4 \\
\hline & & TeamSTEPPS & 1 \\
\hline & & STAT & 3 \\
\hline & & TEAM & 1 \\
\hline & & CTS & 2 \\
\hline & & CPT & 1 \\
\hline & & The Communication and Teamwork Scale & 1 \\
\hline & & Author-developed tool & 28 \\
\hline
\end{tabular}

*Social workers, behavioral health workers, and law enforcement officers; ${ }^{\dagger}$ Duplicate data; CPT, clinical performance tool; CTS, clinical teamwork scale; PA, physician assistant; PRS, pediatric readiness survey; STAT, simulation team assessment tool; TEAM, team emergency assessment measure; TeamSTEPPS, team strategies and tools to enhance performance and patient safety. 
gency Assessment Measure (TEAM), Clinical Teamwork Scale (CTS), Clinical Performance Tool (CPT), and the Communications and Teamwork Scale. Twenty-eight developed tools were used.

\section{The Content of Interprofessional Education for Pe- diatric Emergencies}

The content of IPE education on pediatric emergency situations was analyzed (Table 2). Infancy (birth to 12 months) was the most common stage of pediatric patients, followed by early childhood ( 24 months to 5 years) cases, while there were few programs dealing with premature infants (birth before 37 weeks of gestational age), middle childhood (6 years to 11 years), and late childhood (12 years to 18 years). Simulations were used as an educational strategy used in $90.5 \%(n=19)$ of the examples of IPE. The most commonly used degree of realism or authenticity of the simulation was high-fidelity $(n=14)$. All examples of simulation training used debriefing $(n=18)$, while pre-briefing $(n=10)$ was partially used. As a non-simulation method, lectures $(n=5)$ were used more frequently, followed by other methods, such as skills training $(n=2)$, discussion with video watching $(n=2)$, group case study $(n=1)$ and video conferencing case study $(n=1)$.

\section{Core Components of Interprofessional Education for Pediatric Emergencies}

The IPE core components were synthesized into three themes and eight subthemes. The three themes were individual-competent professionals, team-cooperative professions, and outcome-optimal achievement. Each theme had subthemes for achieving the educational goals. Figure 2 depicts the core components of IPE for pediatric emergencies.

\section{1) Individual-competent professionals}

The 'individual-competent professionals' theme had four subthemes: role and responsibility, clinical judgment, performance, and leadership. The subtheme of role and responsibility was derived from confidence, role clarity, and algorithms as key concepts of education. Twelve studies [Appendix. 1,3,4,7,8,11,14-17,19,21] dealt with role and responsibility. Clinical judgment was derived from decision-making, algorithm-based care, and determining the size or dose as key concepts of education. Eight studies [Appendix. 5-7,11,13,19-21] dealt with clinical judgment. Performance was derived from skill, knowledge, individual performance, and clinical guideline as key concepts of education. Eighteen studies [Appendix. 2,3,5-9,11-21] dealt with performance. Leadership was derived from leadership as a key concept of education. Six studies [Appendix. 1,5,6,9,16,20] dealt with leadership.

\section{2) Team-cooperative professions}

The 'team-cooperative professions' theme had two subthemes: communication and teamwork. Nine studies [Appendix. 2-4,14,15,17-19,21] dealt with communication, and two studies [Appendix. 4,18] researched communication which is the main theme in content such as closed-loop or situation, background, assessment, recommendation (SBAR) approaches to communication. Other studies researched communication as educational content. The teamwork subfactor was derived from team management, team performance, a multidisciplinary team, and collaboration as key concepts of education. Twelve studies [Appendix. 2,3,5-7,9,11,13-15,17,20] dealt with teamwork.

\section{3) Outcome-optimal achievement}

The 'outcome-optimal achievement' theme had two subthemes: patient safety and quality improvement. Patient safety was covered in five studies [Appendix. 5,6,10,13,20]. One study [Appendix. 10] researched only patient safety as a theme, while other studies researched it in addition to the 'individual - competent professionals' or 'team - cooperative professions' themes. Quality improvement was covered in four studies [Appendix. 5,6,9,13]. All studies dealing with quality improvement had three levels of the theme. Quality improvement was a final goal of IPE in five studies [Appendix. 5,6,10, 13,20 ] that dealt with patient safety, and four studies [Appendix. $5,6,9,13$ ] that dealt with quality improvement.

The IPE core components were categorized into three levels: personal (individual), team, and outcome. The components were composed of eight elements-role and responsibility, clinical judgment, performance, leadership, communication, teamwork, patient safety, and quality improvement-that were integrated from the factors evaluated in the research. We found keywords in the studies' purpose, instruments, and results sections. As a measurement instrument is a tool that allows researchers to achieve their purpose by defining a study's methods and results, it is a core component of each study. There were approximately 90 keywords from instruments that we classified into eight categories. Next, the categories were analyzed in three dimensions, as shown in Figure 2. Table 3 shows the IPE core components in the 21 studies. We also classified core components according to Kirkpatrick's [14] outcome level to evaluate educational programs' relevance, engagement, and effectiveness. Almost all studies included two levels of change in attitudes, perceptions, knowledge, or skills (Table 3).

\section{DISCUSSION}

This study was conducted to explore the core components 


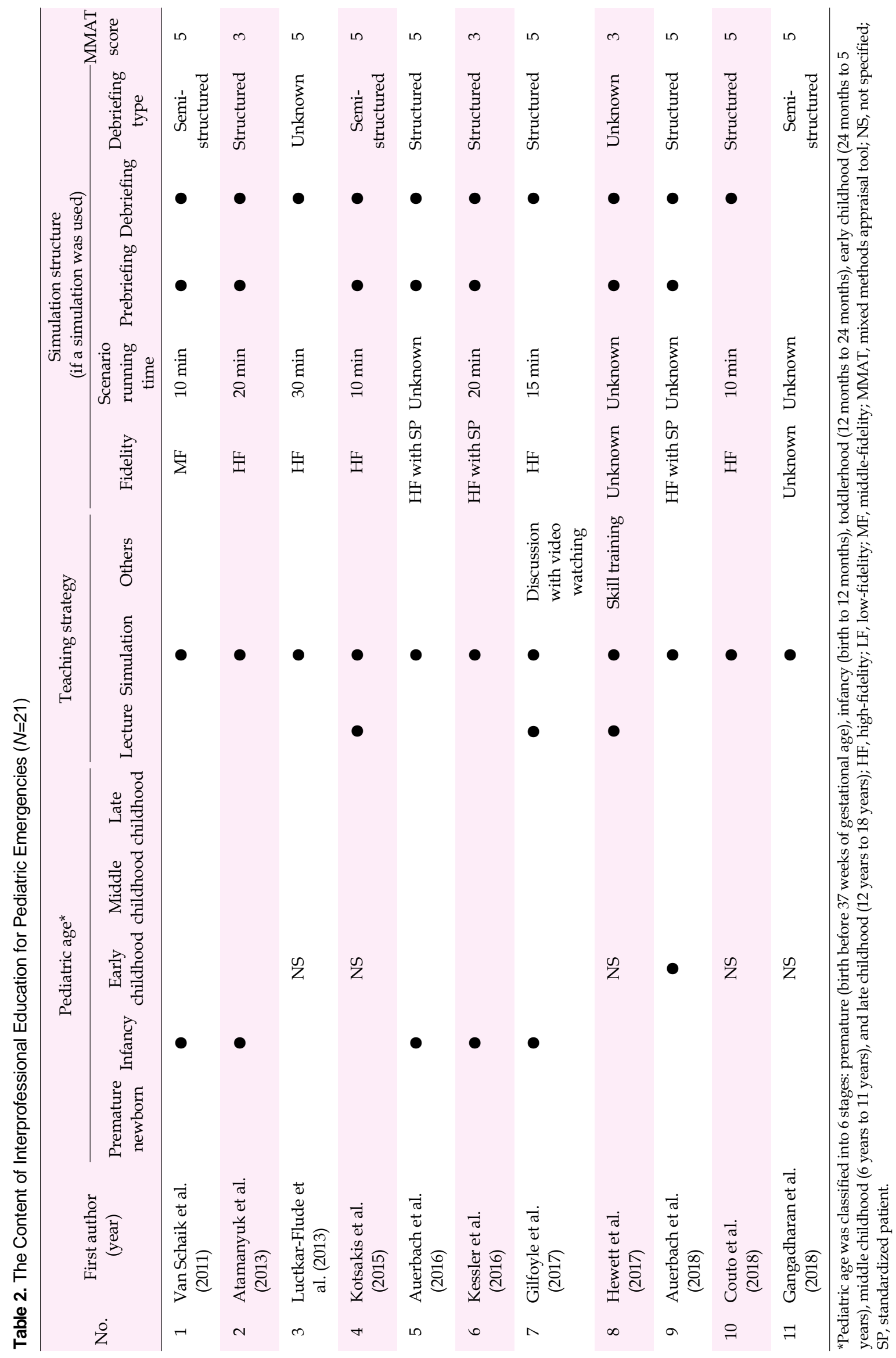




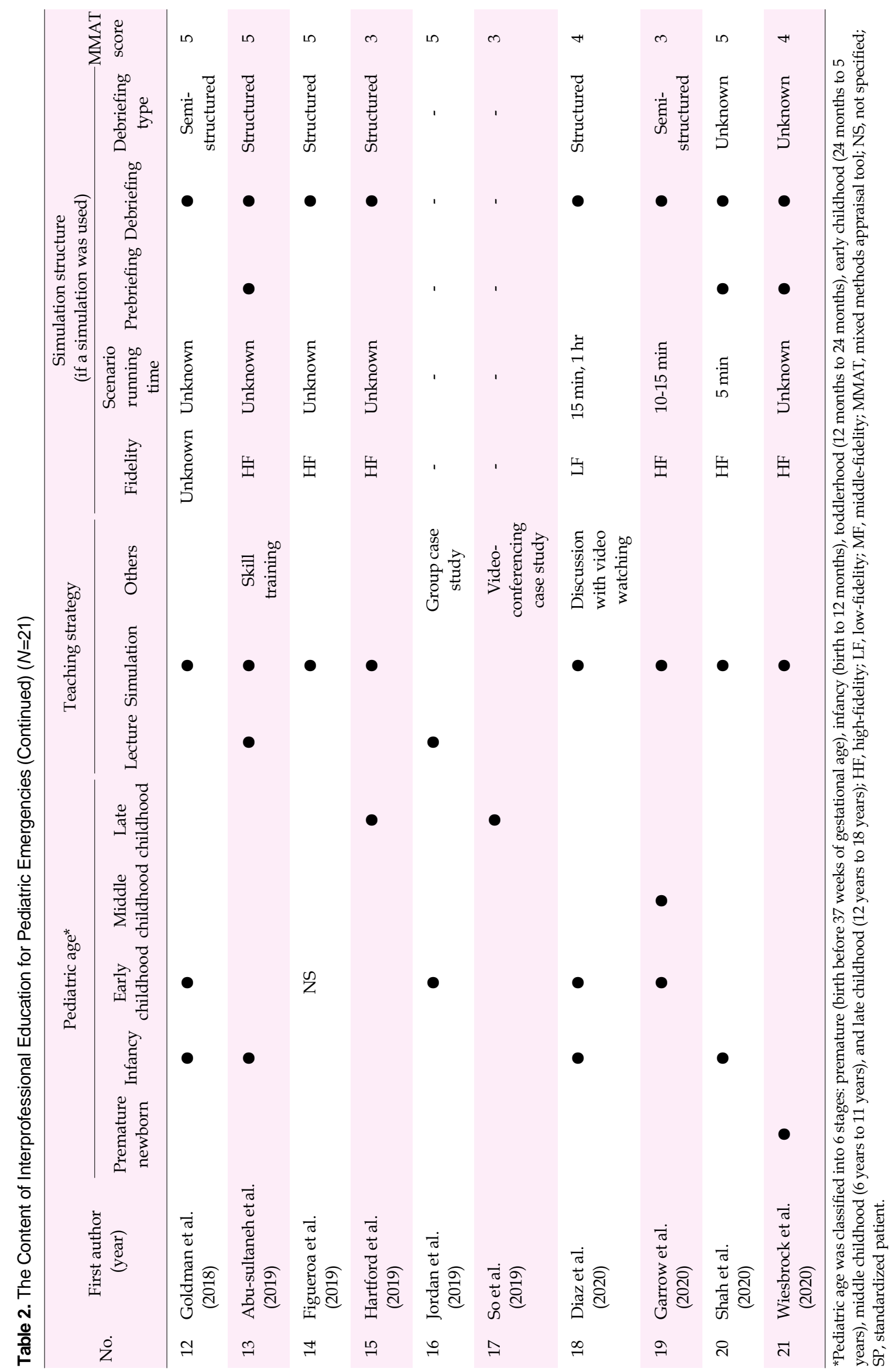




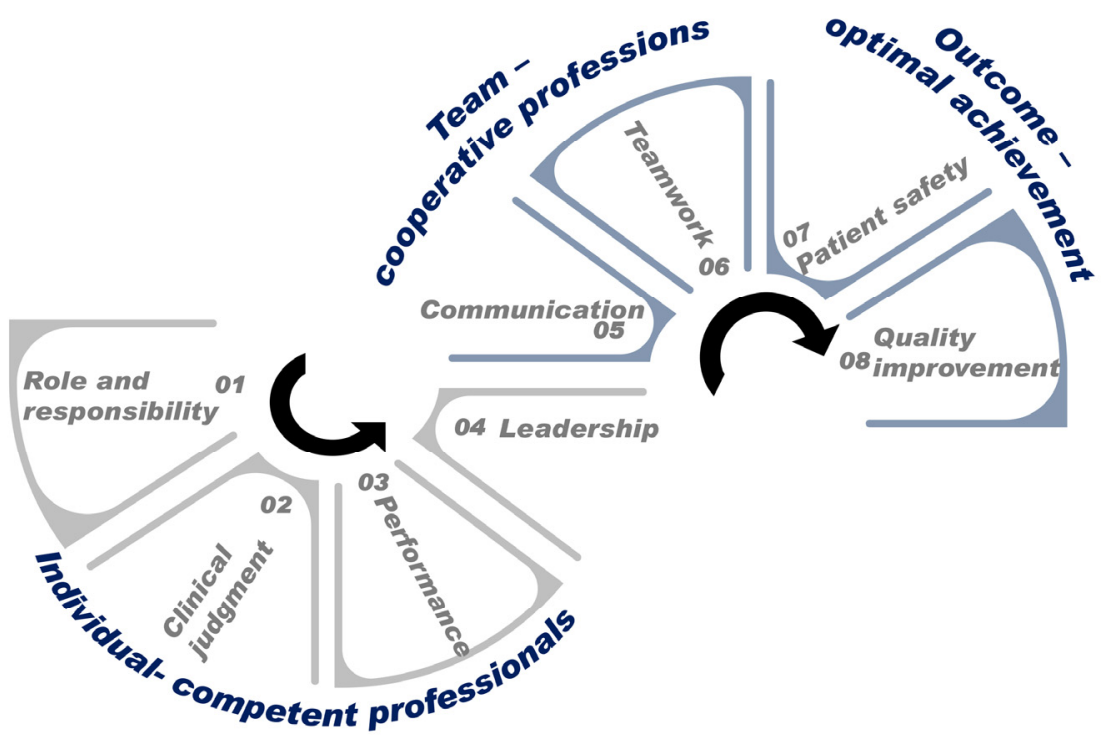

Figure 2. The core components of interprofessional education for pediatric emergencies.

of IPE for pediatric emergencies. We discussed the characteristics and the educational content of the studies, and the core components of IPE for pediatric emergencies.

IPE for pediatric emergencies frequently dealt with cases in infancy and early childhood, which seems necessary in light of the actual types of pediatric emergency situations. Children under the age of 8 are reported to visit the pediatric emergency room more frequently than older children, and children aged 1-4 years visit most frequently $[15,16]$. However, the situations conducted in IPE differ somewhat from the actual frequency of reported pediatric emergency cases, as a report indicated that respiratory disorders were the most frequent reason for visiting a pediatric emergency room in the United States [15], while a study of a single institution in Korea reported a different distribution of causes [16]. A variety of IPE cases could be selected, but effective interprofessional collaboration requires practice with the situations that medical staff face most frequently.

In this study, the characteristics-participants, content of education, and education type-of IPE for pediatric emergencies were analyzed. Most of the evaluated studies conducted education involving nurses and physicians. In clinical practice, because there is no single profession that meets all needs of all patients, interprofessional collaboration (IPC) is an essential principle. Indeed, IPC in the healthcare environment is routine and essential, and is recognized to be especially important for healthcare providers (HCP). In particular, nurses frequently engage in IPC with physicians and are considered to play the most essential role in environments with limited resources [17]. These results were also identified in a study of
HCP in the pediatric department [18]. IPE should also be expanded to nursing students and medical students who are receiving training to become clinical experts because the greatest difficulties experienced in clinical practice are communication and teamwork, which are relevant in most clinical settings.

Nineteen out of 21 studies selected simulation methods in IPE. Simulation-based learning was identified as the most common type of learning method used in IPE dealing with pediatric medical emergencies. Simulation-based education is based on constructivism, which reconstructs knowledge and meaning from learners' experiences [19]. Simulations are an effective educational method in healthcare. IPE using simulations has been reported to be effective for promoting collaboration, communication, mutual understanding of roles, learning of real experience, and other outcomes [20]. This corresponds to the value of IPE presented by the World Health Organization [5] and the core competencies of IPE and collaborative practices guided by IPEC [21]. In healthcare disciplines, simulation-based training is operated on the basis of what can happen in clinical settings, but simulations have the advantages of not causing harm to patients and allowing learners to have a positive learning experience. These results may apply both to professionals who are already working in the clinical field and students who are preparing for clinical work. Significant improvements were identified in both self-awareness and objectively measured IPE competencies for both medical and nursing students in communication, professionalism, shared problem-solving, and shared decision-making after participation in an IPE workshop [21]. By integrating the results above, it is expected that students in 
Table 3. The Core Components and Outcomes of Interprofessional Education in Pediatric Emergencies $(N=21)$

\begin{tabular}{|c|c|c|c|c|c|c|}
\hline $\begin{array}{l}\text { First author } \\
\text { (year) }\end{array}$ & $\begin{array}{c}\text { Research } \\
\text { method }\end{array}$ & Objectives & Country & Education content & Key concepts of education & Themes and subthemes \\
\hline $\begin{array}{l}\text { Van Schaik } \\
\text { et al. (2011) }\end{array}$ & $\begin{array}{l}\text { Mixed } \\
\text { method }\end{array}$ & $\begin{array}{l}\text { To provide a model for } \\
\text { interprofessional team } \\
\text { training }\end{array}$ & USA & PALS & $\begin{array}{l}\text { Leadership, confidence, } \\
\text { self-efficacy }\end{array}$ & $\begin{array}{l}\text { Individual-competent professionals } \\
\text { - Role and responsibility } \\
\text { - Leadership }\end{array}$ \\
\hline $\begin{array}{l}\text { Atamanyuk } \\
\text { et al. (2013) }\end{array}$ & Experimental & $\begin{array}{l}\text { To enhance communication } \\
\text { skills and confidence }\end{array}$ & UK & $\begin{array}{l}\text { Open-chest ECMO } \\
\text { management } \\
\text { Airway management } \\
\text { Resuscitation }\end{array}$ & $\begin{array}{l}\text { Performance, teamwork, } \\
\text { communication skill }\end{array}$ & $\begin{array}{l}\text { Individual-competent professionals } \\
\text { - Performance team-cooperative } \\
\text { professions } \\
\text { - Communication } \\
\text { - Teamwork }\end{array}$ \\
\hline $\begin{array}{l}\text { Luctkar-Flude } \\
\text { et al. (2013) }\end{array}$ & Experimental & $\begin{array}{l}\text { To evaluate an } \\
\text { interprofessional pediatric } \\
\text { education module }\end{array}$ & Canada & $\begin{array}{l}\text { Asthma exacerbation } \\
\text { Sepsis }\end{array}$ & $\begin{array}{l}\text { Skill, confidence, } \\
\text { communication, } \\
\text { teamwork, knowledge, } \\
\text { performance, role } \\
\text { clarity }\end{array}$ & $\begin{array}{l}\text { Individual-competent professionals } \\
\text { - Role and responsibility } \\
\text { - Performance team-cooperative } \\
\text { professions } \\
\text { - Communication } \\
\text { - Teamwork }\end{array}$ \\
\hline $\begin{array}{l}\text { Kotsakis et al. } \\
\text { (2015) }\end{array}$ & Experimental & $\begin{array}{l}\text { To teach identification of } \\
\text { deteriorating patients, } \\
\text { practicing crisis resource } \\
\text { management and basic life } \\
\text { support skills, and using the } \\
\text { SBAR communication tool }\end{array}$ & Canada & $\begin{array}{l}\text { BLS } \\
\text { SBAR communication } \\
\text { Crisis resource } \\
\text { management }\end{array}$ & $\begin{array}{l}\text { Confidence, } \\
\text { communication, role } \\
\text { responsibility }\end{array}$ & $\begin{array}{l}\text { Individual-competent professionals } \\
\text { - Role and responsibility } \\
\text { team-cooperative professions } \\
\text { - Communication }\end{array}$ \\
\hline $\begin{array}{l}\text { Auerbach et al. } \\
\text { (2016) }\end{array}$ & Cohort & $\begin{array}{l}\text { To measure and compare } \\
\text { differences in the quality of } \\
\text { simulated pediatric } \\
\text { resuscitative care provided } \\
\text { by interprofessional teams }\end{array}$ & USA & $\begin{array}{l}\text { Infant foreign body } \\
\quad \text { (warming up/not } \\
\text { included in analyses) } \\
\text { Infant sepsis } \\
\text { Infant seizure } \\
\text { Child cardiac arrest }\end{array}$ & $\begin{array}{l}\text { Skill/knowledge, } \\
\text { clinical judgment, } \\
\text { teamwork, leadership, } \\
\text { team management, } \\
\text { quality improvement, } \\
\text { patient safety }\end{array}$ & $\begin{array}{l}\text { Individual-competent profession } \\
\text { - Performance } \\
\text { - Clinical judgment } \\
\text { - Leadership team-cooperative } \\
\text { professions } \\
\text { - Teamwork outcome-optimal } \\
\text { achievement } \\
\text { - Patient safety } \\
\text { - Quality improvement }\end{array}$ \\
\hline $\begin{array}{l}\text { Kessler et al. } \\
\text { (2016) }\end{array}$ & $\begin{array}{l}\text { Qualitative } \\
\text { analysis }\end{array}$ & $\begin{array}{l}\text { To measure and compare } \\
\text { adherence to pediatric sepsis } \\
\text { guidelines across a spectrum } \\
\text { of emergency departments }\end{array}$ & USA & $\begin{array}{l}\text { Septic shock treatment } \\
\text { - Foreign body } \\
\text { aspiration } \\
\text { - Sepsis } \\
\text { - Seizure } \\
\text { - Cardiac arrest }\end{array}$ & $\begin{array}{l}\text { Skill (performance), } \\
\text { team performance, } \\
\text { emergency readiness, } \\
\text { clinical judgment, } \\
\text { patient safety, } \\
\text { knowledge, } \\
\text { leadership, quality } \\
\text { improvement }\end{array}$ & $\begin{array}{l}\text { Individual-competent professionals } \\
\text { - Performance } \\
\text { - Clinical judgment } \\
\text { - Leadership team-cooperative } \\
\text { professions } \\
\text { - Teamwork outcome-optimal } \\
\text { achievement } \\
\text { - Patient safety } \\
\text { - Quality improvement }\end{array}$ \\
\hline $\begin{array}{l}\text { Gilfoyle et al. } \\
\text { (2017) }\end{array}$ & Experimental & $\begin{array}{l}\text { To measure the effect of the } \\
\text { program, team efficiency, } \\
\text { and teamwork in a simulated } \\
\text { clinical environment }\end{array}$ & Canada & $\begin{array}{l}\text { PALS } \\
\text { - Cardiogenic shock } \\
\text { leading to VT } \\
\text { - Unstable SVT } \\
\text { - Asystole }\end{array}$ & $\begin{array}{l}\text { Performance, team } \\
\text { efficiency, teamwork, } \\
\text { clinical judgment, role } \\
\text { and responsibility, } \\
\text { situational awareness, } \\
\text { decision making }\end{array}$ & $\begin{array}{l}\text { Individual-competent professionals } \\
\text { - Role and responsibility } \\
\text { - Performance } \\
\text { - Clinical judgment } \\
\text { team-cooperative professions } \\
\text { - Teamwork }\end{array}$ \\
\hline $\begin{array}{l}\text { Hewett et al. } \\
\text { (2017) }\end{array}$ & Experimental & $\begin{array}{l}\text { To provide pediatric ED } \\
\text { providers with the skills and } \\
\text { knowledge necessary to } \\
\text { respond to a HAZMAT event. }\end{array}$ & USA & $\begin{array}{l}\text { PAPR use in pediatric } \\
\text { hazardous material } \\
\text { incident }\end{array}$ & $\begin{array}{l}\text { Skill (performance), } \\
\text { knowledge, confidence }\end{array}$ & $\begin{array}{l}\text { Individual-competent professionals } \\
\text { - Role and responsibility } \\
\text { - Performance }\end{array}$ \\
\hline $\begin{array}{l}\text { Auerbach et al. } \\
\text { (2018) }\end{array}$ & Experimental & $\begin{array}{l}\text { To develop a multidisciplinary } \\
\text { pediatric airway management } \\
\text { course to emphasize the } \\
\text { importance of communication } \\
\text { and cooperation across } \\
\text { subspecialties and provide a } \\
\text { common skill set and } \\
\text { knowledge base for novice } \\
\text { subspecialty trainees. }\end{array}$ & USA & $\begin{array}{l}\text { Foreign body } \\
\quad \text { aspiration } \\
\text { Sepsis } \\
\text { Seizure } \\
\text { Cardiac arrest }\end{array}$ & $\begin{array}{l}\text { Individual performance, } \\
\text { team performance, } \\
\text { teamwork, leadership, } \\
\text { team management, } \\
\text { skill, quality } \\
\text { improvement, } \\
\text { environmental } \\
\text { management }\end{array}$ & $\begin{array}{l}\text { Individual-competent professionals } \\
\text { - Performance } \\
\text { - Leadership team-cooperative } \\
\text { professions } \\
\text { - Teamwork outcome-optimal } \\
\text { achievement } \\
\text { - Quality improvement }\end{array}$ \\
\hline
\end{tabular}

BLS, basic life support; CED, community emergency departments; CPR, cardiopulmonary resuscitation; ECMO, extracorporeal membrane oxygenation; ED, emergency department; GED, gneral emergency department; HAZMAT, hzardous materials; LST, ltent safety threats; NRP, nonatal resuscitation program; PALS, pediatric advanced life support; PAPR, powered air purifying respirator; PCICU, pediatric cardiac intensive care unit; PED, pediatric emergency department; RDS, respiratory distress syndrome; SBAR, situation, background, assessment, recommendation; SVT, supra-ventricular tachycardia; VT, ventricular tachycardia. 
Table 3. The Core Components and Outcomes of Interprofessional Education in Pediatric Emergencies (Continued) $(N=21)$

\begin{tabular}{|c|c|c|c|c|c|c|}
\hline $\begin{array}{l}\text { First author } \\
\text { (year) }\end{array}$ & $\begin{array}{l}\text { Research } \\
\text { method }\end{array}$ & Objectives & Country & Education content & Key concepts of education & Themes and subthemes \\
\hline $\begin{array}{l}\text { Couto et al. } \\
\text { (2018) }\end{array}$ & Experimental & $\begin{array}{l}\text { To improve } \\
\text { management of } \\
\text { critically ill patients } \\
\text { admitted to the } \\
\text { emergency bay }\end{array}$ & Brazil & $\begin{array}{l}\text { Arrhythmia } \\
\text { Respiratory } \\
\text { insufficiency } \\
\text { Shock } \\
\text { Cardiopulmonary } \\
\text { resuscitation }\end{array}$ & $\begin{array}{l}\text { Patient safety, resource } \\
\text { management }\end{array}$ & $\begin{array}{l}\text { Outcome-optimal achievement } \\
\text { - Patient safety }\end{array}$ \\
\hline $\begin{array}{l}\text { Gangadharan } \\
\text { et al. (2018) }\end{array}$ & $\begin{array}{c}\text { Qualitative } \\
\text { approach }\end{array}$ & $\begin{array}{l}\text { To explore PED and } \\
\text { GED providers' } \\
\text { perceptions of caring } \\
\text { for critically ill infants } \\
\text { and children }\end{array}$ & USA & $\begin{array}{l}\text { Foreign body } \\
\text { aspiration } \\
\text { Seizure } \\
\text { Septic shock } \\
\text { Cardiac arrest }\end{array}$ & $\begin{array}{l}\text { Comfort with } \\
\text { algorithm-based care } \\
\text { Reliance on cognitive aids } \\
\text { and use of } \\
\text { experience-based recall } \\
\text { Pediatric emergency } \\
\text { department providers } \\
\text { relied on large } \\
\text { multidisciplinary teams to } \\
\text { minimize multitasking } \\
\text { Discomfort with locating, } \\
\text { determining the size, } \\
\text { determining the dose, and } \\
\text { using pediatric-specific } \\
\text { equipment and } \\
\text { medications }\end{array}$ & $\begin{array}{l}\text { Individual-competent professionals } \\
\text { - Role and responsibility } \\
\text { - Clinical judgment } \\
\text { - Performance team-cooperative } \\
\text { professions } \\
\text { - Teamwork }\end{array}$ \\
\hline $\begin{array}{l}\text { Goldman et al. } \\
\text { (2018) }\end{array}$ & $\begin{array}{l}\text { Mixed } \\
\text { method }\end{array}$ & $\begin{array}{l}\text { To explore interprofessional } \\
\text { CED providers' } \\
\text { perceptions of caring for } \\
\text { pediatric patients. }\end{array}$ & USA & $\begin{array}{l}\text { Upper airway } \\
\text { obstruction from a } \\
\text { foreign body } \\
\text { Septic shock } \\
\text { Febrile status } \\
\text { epilepticus } \\
\text { Cardiopulmonary } \\
\text { arrest from } \\
\text { drowning }\end{array}$ & Confidence, skill, knowledge & $\begin{array}{l}\text { Individual-competent professionals } \\
\text { - Performance }\end{array}$ \\
\hline $\begin{array}{l}\text { Abu-sultaneh } \\
\text { et al. (2019) }\end{array}$ & Experimental & $\begin{array}{l}\text { To improve pediatric } \\
\text { airway management } \\
\text { and pediatric } \\
\text { emergency readiness }\end{array}$ & USA & Airway management & $\begin{array}{l}\text { Emergency readiness, } \\
\text { performance, team } \\
\text { management, quality } \\
\text { improvement, patient } \\
\text { safety, skill, knowledge, } \\
\text { clinical judgment }\end{array}$ & $\begin{array}{l}\text { Individual-competent professionals } \\
\text { - Performance } \\
\text { - Clinical judgment } \\
\text { team-cooperative professions } \\
\text { - Teamwork outcome-optimal } \\
\text { achievement } \\
\text { - Patient safety } \\
\text { - Quality improvement }\end{array}$ \\
\hline $\begin{array}{l}\text { Figueroa et al. } \\
\text { (2019) }\end{array}$ & Experimental & $\begin{array}{l}\text { To improve teamwork } \\
\text { and communication } \\
\text { skills as well as } \\
\text { knowledge and } \\
\text { technical skills among } \\
\text { a multidisciplinary } \\
\text { PCICU team }\end{array}$ & USA & $\begin{array}{l}\text { Airway emergency } \\
\text { Neurologic } \\
\text { emergency } \\
\text { Cardiac emergency }\end{array}$ & $\begin{array}{l}\text { Skill (performance), } \\
\text { confidence, } \\
\text { communication, } \\
\text { collaboration, role and } \\
\text { responsibility, teamwork }\end{array}$ & $\begin{array}{l}\text { Individual-competent professionals } \\
\text { - Role and responsibility } \\
\text { - Performance team-cooperative } \\
\text { professions } \\
\text { - Communication } \\
\text { - Teamwork }\end{array}$ \\
\hline $\begin{array}{l}\text { Hartford et al. } \\
\text { (2019) }\end{array}$ & Experimental & $\begin{array}{l}\text { To enhance the } \\
\text { management of } \\
\text { patients with } \\
\text { bupropion overuse }\end{array}$ & USA & $\begin{array}{l}\text { Altered } \\
\text { consciousness and } \\
\text { general tonic-clonic } \\
\text { seizure in drug } \\
\text { overuse } \\
\text { PALS }\end{array}$ & $\begin{array}{l}\text { Clinical performance, } \\
\text { knowledge, teamwork, } \\
\text { communication, confidence }\end{array}$ & $\begin{array}{l}\text { Individual-competent professionals } \\
\text { - Role and responsibility } \\
\text { - Performance team-cooperative } \\
\text { professions } \\
\text { - Teamwork } \\
\text { - Communication }\end{array}$ \\
\hline $\begin{array}{l}\text { Jordan et al. } \\
\text { (2019) }\end{array}$ & $\begin{array}{l}\text { Mixed } \\
\text { method }\end{array}$ & $\begin{array}{l}\text { To enhance patient } \\
\text { outcomes, teamwork, } \\
\text { mentorship }\end{array}$ & USA & $\begin{array}{l}\text { Pediatric sexual } \\
\text { abuse }\end{array}$ & $\begin{array}{l}\text { Knowledge, confidence, } \\
\text { self-efficacy, clinical } \\
\text { guideline adherence, } \\
\text { leadership }\end{array}$ & $\begin{array}{l}\text { Individual-competent professionals } \\
\text { - Role and responsibility } \\
\text { - Performance } \\
\text { - Leadership }\end{array}$ \\
\hline
\end{tabular}

BLS, basic life support; CED, community emergency departments; CPR, cardiopulmonary resuscitation; ECMO, extracorporeal membrane oxygenation; ED, emergency department; GED, gneral emergency department; HAZMAT, hzardous materials; LST, ltent safety threats; NRP, nonatal resuscitation program; PALS, pediatric advanced life support; PAPR, powered air purifying respirator; PCICU, pediatric cardiac intensive care unit; PED, pediatric emergency department; RDS, respiratory distress syndrome; SBAR, situation, background, assessment, recommendation; SVT, supra-ventricular tachycardia; VT, ventricular tachycardia. 
Table 3. The Core Components and Outcomes of Interprofessional Education in Pediatric Emergencies $($ Continued $)(N=21)$

\begin{tabular}{|c|c|c|c|c|c|c|}
\hline $\begin{array}{l}\text { First author } \\
\text { (year) }\end{array}$ & $\begin{array}{c}\text { Research } \\
\text { method }\end{array}$ & Objectives & Country & Education content & Key concepts of education & Themes and subthemes \\
\hline So et al. (2019) & $\begin{array}{l}\text { Mixed } \\
\text { method }\end{array}$ & $\begin{array}{l}\text { To assess participants' } \\
\text { knowledge and } \\
\text { confidence to fulfill } \\
\text { targeted federal } \\
\text { preparedness } \\
\text { capabilities }\end{array}$ & USA & $\begin{array}{l}\text { Smallpox and } \\
\text { unknown infections } \\
\text { Vaccination } \\
\text { School system about } \\
\text { closures or delayed } \\
\text { opening }\end{array}$ & $\begin{array}{l}\text { Knowledge, confidence, } \\
\text { collaboration, } \\
\text { performance, } \\
\text { communication }\end{array}$ & $\begin{array}{l}\text { Individual-competent professionals } \\
\text { - Role and responsibility } \\
\text { - Performance team-cooperative } \\
\text { professions } \\
\text { - Teamwork } \\
\text { - Communication }\end{array}$ \\
\hline $\begin{array}{l}\text { Diaz et al. } \\
\quad(2020)\end{array}$ & $\begin{array}{c}\text { Qualitative } \\
\text { approach }\end{array}$ & $\begin{array}{l}\text { To improve closed-loop } \\
\text { communication ability } \\
\text { and decrease medical } \\
\text { error }\end{array}$ & USA & $\begin{array}{l}\text { Closed-loop } \\
\text { communication in } \\
\text { CPR situation }\end{array}$ & $\begin{array}{l}\text { Performance, error in the } \\
\text { situation, } \\
\text { communication }\end{array}$ & $\begin{array}{l}\text { Individual-competent professionals } \\
\text { - Performance team-cooperative } \\
\text { professions } \\
\text { - Communication }\end{array}$ \\
\hline $\begin{array}{l}\text { Garrow et al. } \\
(2020)\end{array}$ & Experimental & $\begin{array}{l}\text { To evaluate RDS } \\
\text { management in an } \\
\text { emergency situation }\end{array}$ & USA & $\begin{array}{l}\text { Respiratory distress } \\
\text { management } \\
\text { Seizure management }\end{array}$ & $\begin{array}{l}\text { Team performance, } \\
\text { communication, role } \\
\text { responsibility, } \\
\text { situational awareness, } \\
\text { and decision-making }\end{array}$ & $\begin{array}{l}\text { Individual-competent professionals } \\
\text { - Role and responsibility } \\
\text { - Clinical judgment } \\
\text { - Performance team-cooperative } \\
\text { professions } \\
\text { - Communication }\end{array}$ \\
\hline $\begin{array}{l}\text { Shah et al. } \\
\text { (2020) }\end{array}$ & $\begin{array}{r}\text { Qualitative } \\
\text { approach }\end{array}$ & $\begin{array}{l}\text { To assess the clinical } \\
\text { environment and } \\
\text { identify LSTs related to } \\
\text { the management of } \\
\text { pediatric tracheostomy } \\
\text { patients using in situ } \\
\text { simulation } \\
\text { To analyze the effects of } \\
\text { systems interventions } \\
\text { and team factors on } \\
\text { LSTs and simulation } \\
\text { performance }\end{array}$ & USA & $\begin{array}{l}\text { Tracheostomy tube } \\
\text { obstruction }\end{array}$ & $\begin{array}{l}\text { Performance, teamwork, } \\
\text { critical thinking, } \\
\text { leadership, teamwork, } \\
\text { task management, } \\
\text { patient safety, clinical } \\
\text { judgment }\end{array}$ & $\begin{array}{l}\text { Individual-competent professionals } \\
\text { - Clinical judgment } \\
\text { - Performance } \\
\text { - Leadership team-cooperative } \\
\text { professions } \\
\text { - Teamwork outcome-optimal } \\
\text { achievement } \\
\text { - Patient safety }\end{array}$ \\
\hline $\begin{array}{l}\text { Wiesbrock } \\
\text { et al. (2020) }\end{array}$ & Experimental & $\begin{array}{l}\text { To implement a } \\
\text { simulation program in a } \\
\text { community hospital } \\
\text { setting that supports } \\
\text { standardized } \\
\text { evidence-based delivery } \\
\text { room practices for } \\
\text { premature infants born } \\
\text { at less than } 30 \text { weeks' } \\
\text { gestation }\end{array}$ & USA & $\begin{array}{l}\text { NRP } \\
\text { - Resuscitation } \\
\text { - Thermoregulation } \\
\text { - Communication } \\
\text { - Equipment/supplies }\end{array}$ & $\begin{array}{l}\text { Clinical performance, } \\
\text { confidence, } \\
\text { communication, clinical } \\
\text { judgment, } \\
\text { environmental } \\
\text { management }\end{array}$ & $\begin{array}{l}\text { Individual-competent professionals } \\
\text { - Role and responsibility } \\
\text { - Clinical judgment } \\
\text { - Performance team-cooperative } \\
\text { professions } \\
\text { - Communication }\end{array}$ \\
\hline
\end{tabular}

BLS, basic life support; CED, community emergency departments; CPR, cardiopulmonary resuscitation; ECMO, extracorporeal membrane oxygenation; ED, emergency department; GED, gneral emergency department; HAZMAT, hzardous materials; LST, ltent safety threats; NRP, nonatal resuscitation program; PALS, pediatric advanced life support; PAPR, powered air purifying respirator; PCICU, pediatric cardiac intensive care unit; PED, pediatric emergency department; RDS, respiratory distress syndrome; SBAR, situation, background, assessment, recommendation; SVT, supra-ventricular tachycardia; VT, ventricular tachycardia.

healthcare, particularly in pediatrics, will be more prepared after participating in simulation-based IPE training. As professionals, many participants must share their experiences with those from other professions. Therefore, in the first tier of debriefing, a same-profession debriefing is effective for sharing learning experiences about clinical judgment and critical thinking, and, in the second tier, debriefing among multiple professions is more effective for discussing the learning experiences, communication, teamwork, and the role of each profession [22]. This approach can enhance participants' psychological safety and ensure a more effective learning experience. In addition to simulation, other educational methods, such as lectures, skill training and discussion with video watching, were often used to achieve educational objectives effectively.
In this study, the educational components consisted of three areas: 1) individual-competent professionals, 2) team-cooperative professions, and 3) outcomes-optimal achievements. Each theme had subthemes for enhancing the effectiveness of IPE for pediatric emergencies, which were integratively derived.

\section{Individual-Competent Professionals}

Most studies had educational content related to individuals as competent professionals. In the learning objectives of IPE, the first and basic step is the 'individual-competent professional' theme, which consists of role and responsibility, clinical judgment, performance and leadership. The subtheme 
of role and responsibility is important because it relates to professional intuition, values, philosophy, and the norms of clinical judgment. The inclusion of the 'individual-competent professional' component in IPE is consistent with the consideration of the continuum of multi-disciplinary practices and interprofessional practices. Multi-disciplinary practices exist as the most fundamental stages of interprofessional practices and education. From the perspective of multi-disciplinary practices, the unique role and function of each specific individual profession for patient care are important. Individuals can understand this and effectively perform in their field, and this competency can be used for leadership in dynamics with other professionals. Al-Eraky and Marei [23] reported a new paradigm in which Miller's pyramid, formerly used as the main framework for evaluating health professionals, was utilized to evaluate learners at a team level beyond individuals. If one exercises his or her competencies as a leader at the highest "do" level, the "leadership" component at the individual level has been reached. Since the clinical environment requires team competencies as well as individual competencies, recent educational strategies have sought to use various methods for working with colleagues rather than remaining at the individual levels. These methods include team-based learning and IPE. Therefore, the evaluation of individuals as team members should also be considered.

\section{Team-Cooperative Professions}

In IPE, it is also necessary to allow learners to form, act, and be evaluated as a team made up of individuals from cooperative professions. The abilities or competencies of an individual never guarantee the abilities or competence of a team, nor does a group of competent individuals automatically form a competent team [24]. In clinical practice, because no single profession meets all needs of all patients, IPC is an essential principle. Indeed, IPC in the healthcare environment is routine and essential, and is recognized to be especially important for HCP. In particular, nurses frequently engage in IPC with physicians and are considered to play the most essential role in environments with limited resources [17]. Just as nurses and physicians are the most frequently identified HCPs in IPC in practice, this study and others [18] also showed that most examples of IPE in pediatric settings were conducted with nurses and physicians. One of the important purposes of IPE is to work as a team in practice, but fewer than half of the studies included in this study presented IPE involving teamwork and communication (i.e., reflecting the theme of team-cooperative professions). From a variety of perspectives, communication is a major determinant of health, and in clinical settings, medical professionals' communication with various people is ultimately reflected in patient outcomes [25]. For this reason, the healthcare community strives to create a "common language" according to the context of clinical situations, such as the use of standardized tools for effective communication (for example, the SBAR and acknowledgeintroduce-duration-explanation-thank you [AIDET] communication frameworks) or the implementation of clinical standards that provide checklists and briefings according to circumstances [26]. Moreover, IPE helps to overcome the inefficiency caused by communication inconsistencies among team members. Since the greatest difficulties experienced in clinical practice are communication and teamwork, which are relevant in most clinical settings, the expansion of IPE to undergraduate healthcare students will help them practice and overcome these difficulties in advance.

\section{Outcome-Optimal Achievement}

The last theme was 'outcome-optimal achievement.' Four studies dealt with both patient safety and quality improvement, and two studies addressed patient safety or quality improvement. Kirkpatrick [14] described four levels of education evaluation: level 1 evaluates the learner's response; level 2 includes the learner's attitude, understanding, knowledge, and skill acquisition; level 3 deals with the change in the learner's individual professional practice; and in level 4, changes in the organization's (team) performance and patient outcomes are evaluated. The theme of 'outcome - optimal achievement' corresponds to the ultimate educational goal, but only six studies dealt with it explicitly. Optimal achievement is considered to require long-term follow-up and an appropriate tool for evaluation has not been developed. IPE for pediatric emergencies ultimately aims to improve patient safety and quality of care, as is the case for education in other health professions. Since outstanding individual competencies can yield optimal patient outcomes through teamwork, purposeful education should be provided to facilitate organic interconnections. This should be done with a consistent purpose, from educational program planning to evaluation.

In this study, the core components of IPE were limited to IPE for pediatric emergencies. Therefore, there is a limit to generalizing these findings to the core components of IPE in general. Follow-up studies dealing with a greater variety of IPE research, or even a comprehensive range of IPE, would enable the establishment of an effective strategy for IPE design. Further, acknowledging the complexity of the design of IPE, we suggest conducting further studies on the development of structured templates to achieve optimal results from IPE and studies revealing its actual effectiveness. We also suggest continuing research on IPE for pediatric emergencies 
with tools that have established reliability and validity, since many researchers used self-developed tools to evaluate the effectiveness of IPE. These tools were heterogeneous in terms of structure and composition, and also lacked assessments of validity and reliability. Thus, it was difficult to standardize assessments of the effectiveness of education. These issues have been pointed out in previous studies [27]. Most of the critically appraised tools for measuring IPE and IPC outcomes in pre-licensed healthcare professionals have limited reliability and validity [28]. For discernment among trainees and to enable the valid interpretation of results, appropriate instruments should have clear evidence regarding their psychometric properties. As IPE is becoming a global trend in HCP education, validated standard tools are needed to evaluate education and its effectiveness.

\section{CONCLUSION}

IPE positively impacts patient outcomes by ensuring preparation for IPC, which is routine in the medical environment. The core components of IPE for pediatric emergencies included three dimensions: individual, team, and outcome. The individual level was related to personal abilities such as knowledge, performance, and attitude. The team level was related to communication and teamwork. What we most hope to gain through IPE is patient safety and quality improvement as an eventual outcome. For this education to be carried out effectively, it must be well designed in accordance with its goal. Therefore, for IPE to be effective for promoting personal growth, team growth, organizational growth, and eventually patient outcomes, due consideration should be given starting from the point of planning the IPE program. The level of the results also must be considered according to these steps: acknowledging the complexity of the design of IPE, developing structured templates to achieve optimal consequences, and suggesting follow-up research to reveal its effectiveness.

In this study, we reviewed the results of real-world examples of IPE for pediatric emergency situations and identified its core components with three levels and eight elements. The three themes were individual-competent professionals (subthemes: role and responsibility, clinical judgment, performance, and leadership), team-cooperative professions (subthemes: communication and teamwork), and outcome-optimal achievement (subthemes: patient safety and quality improvement). For IPE to be effective for promoting personal growth, team growth, organizational growth, and eventual patient outcomes, due consideration should be given to the planning of educational programs from the beginning. The purpose and characteristics of IPE, including its core components, must be considered.

\section{ORCID}

Soonyoung Shon

https://orcid.org/0000-0003-0571-2181

Hyejin Jeon

https://orcid.org/0000-0003-3657-4017

Heejin Hwang

\section{Authors' contribution}

Conceptualization: all authors; Data collection: Soonyoung Shon; Formal analysis: all authors; Writing-original draft: all authors; Writing-review and editing: Soonyoung Shon; Final approval of published version: all authors.

\section{Conflict of interest}

No existing or potential conflict of interest relevant to this article was reported.

\section{Funding}

This study was supported by a National Research Foundation of Korea (NRF) grant funded by the Korean government (MSIT) (NRF-2020R1G1A1101810).

\section{Data availability}

Please contact the corresponding author for data availability.

\section{Acknowledgements}

None.

\section{REFERENCES}

1. Killam LA, Heerschap C. Challenges to student learning in the clinical setting: A qualitative descriptive study. Nurse Education Today. 2013;33(6):684-691. https://doi.org/10.1016/j.nedt.2012.10.008

2. Adib-Hajbaghery $M$, Sharifi $N$. Effect of simulation training on the development of nurses and nursing students' critical thinking: A systematic literature review. Nurse Education Today. 2017;50:17-24. https://doi.org/10.1016/j.nedt.2016.12.011

3. Kim M, Kim S, Lee WS. Effects of a virtual reality simulation and a blended simulation of care for pediatric patient with asthma. Child Health Nursing Research. 2019;25(4):496-506.

https://doi.org/10.4094/chnr.2019.25.4.496

4. Vuurberg G, Vos JAM, Christoph LH, de Vos R. The effectiveness of interprofessional classroom-based education in medical curricula: A systematic review. Journal of Interprofessional Education and Practice. 2019;15(November 2018):157-167. 
https://doi.org/10.1016/j.xjep.2019.01.007

5. World Health Oraganization. Framework for action on interprofessional education and collaborative practice [Internet]. Geneva: Health Professions Networks Nursing and Midwifery Human Resource for Health; 2010 [cited 22 Mar 2021]. Available from: https://www.who.int/hrh/resources/framework_action/en/

6. Cunningham S, Foote L, Sowder M, Cunningham C. Interprofessional education and collaboration: A simulation-based learning experience focused on common and complementary skills in an acute care environment. Journal of Interprofessional Care. 2018; 32(3):395-398. https://doi.org/10.1080/13561820.2017.1411340

7. Costello M, Prelack K, Faller J, Huddleston J, Adly S, Doolin J. Student experiences of interprofessional simulation: Findings from a qualitative study. Journal of Interprofessional Care. 2018;32(1): 95-97. https://doi.org/10.1080/13561820.2017.1356810

8. Edwards KJM. ISBARR communication workshop and its effect on novice baccalaureate nursing students' self-confidence [master's thesis]. Pueblo: Colorado State University; 2016. p. 1-60

9. Jang YL, Lee HW, Ko MS, Wang MS. Study on factors affecting job stress of new nurses. Asia-pacific Journal of Multimedia Services Convergent with Art, Humanities, and Sociology. 2018;8(2): 793-803. https://doi.org/10.35873/ajmahs.2018.8.2.078

10. Rosenstein AH, Naylor B. Incidence and impact of physician and nurse disruptive behaviors in the emergency department. The Journal of Emergency Medicine. 2012;43(1):139-148. https://doi.org/10.1016/j.jemermed.2011.01.019

11. Whittemore R, Knafl K. The integrative review: Updated methodology. Journal of Advanced Nursing. 2006;52(5):546-553. https://doi.org/10.1111/j.1365-2648.2005.03621.x

12. Buring SM, Bhushan A, Broeseker A, Conway S, Duncan-Hewitt W, Hansen L, et al. Interprofessional education: Definitions, student competencies, and guidelines for implementation. American Journal of Pharmaceutical Education. 2009;73(4):59. https://doi.org/10.5688/aj730459

13. Hong QN, Fàbregues S, Bartlett G, Boardman F, Cargo M, Dagenais $\mathrm{P}$, et al. The Mixed Methods Appraisal Tool (MMAT) version 2018 for information professionals and researchers. Education for Information. 2018;34(4):285-291.

https://doi.org/10.3233/EFI-180221

14. Kirkpatrick JD, Kirkpatrick WK. Kirkpatrick's four levels of training evalution. 1st ed. Newnan, GA: Association for Talent Development; 2016. p. 20-58.

15. McDermott KW, Stocks C, Freeman WJ. Overview of pediatric emergency department visits, 2015: Statistical brief \#242 [Internet]. Rockville: Agency for Healthcare Research and Quality; 2018 [cited 21 Mar 2021]. Available from: https://www.ncbi.nlm.nih.gov/books/NBK526418

16. Shin S, Choi HJ, Choi B. Utilization characteristics of an advanced pediatric emergency center: A single center study over 2 years. Pediatric Emergency Medicine Journal. 2020;7(1):16-22.
17. Koff SZ. Nursing in the European Union: Anatomy of a profession. 1st ed. UK: Routledge; 2016. p. 183-238.

18. Straub C, Heinzmann A, Krueger M, Bode SFN. Nursing staff's and physicians' acquisition of competences and attitudes to interprofessional education and interprofessional collaboration in pediatrics. BMC Medical Education. 2020;20(1):213. https://doi.org/10.1186/s12909-020-02128-y

19. Weeks KW, Coben D, O'Neill D, Jones A, Weeks A, Brown M, et al. Developing and integrating nursing competence through authentic technology-enhanced clinical simulation education: Pedagogies for reconceptualising the theory-practice gap. Nurse Education in Practice. 2019;37:29-38.

https://doi.org/10.1016/j.nepr.2019.04.010

20. Titzer JL, Swenty CF, Hoehn WG. An interprofessional simulation promoting collaboration and problem solving among nursing and allied health professional students. Clinical Simulation in Nursing. 2012;8(8):325-333. https://doi.org/10.1016/j.ecns.2011.01.001

21. Interprofessional Educational Collaborative. Core competencies for interprofessional collaborative practice: 2016 Update. Washington, DC: Interprofessional Education Collaborative; 2016. p. 10-11.

22. Andersen P, Coverdale S, Kelly M, Forster S. Interprofessional simulation: Developing teamwork using a two-tiered debriefing approach. Clinical Simulation in Nursing. 2018;20:15-23. https://doi.org/10.1016/j.ecns.2018.04.003

23. Al-Eraky M, Marei H. A fresh look at Miller's pyramid: Assessment at the 'Is' and 'Do' levels. Medical Education. 2016;50(12): 1253-1257. https://doi.org/10.1111/medu.13101

24. King HB, Battles J, Baker DP, Alonso A, Salas E, Webster J, et al. TeamSTEPPS ${ }^{\mathrm{TM}}$ : Team strategies and tools to enhance performance and patient safety. In: Henriksen K, Battles JB, Keyes MA, editors. Advances in patient safety: New directions and alternative approaches (Vol 3: Performance and tools) [Internet]. Rockville: Agency for Healthcare Research and Quality; 2008. Available from: http://www.ahrq.gov/qual/teamstepps/

25. Wolderslund M, Kofoed PE, Ammentorp J. The effectiveness of a person-centred communication skills training programme for the health care professionals of a large hospital in Denmark. Patient Education and Counseling. 2021;104(6):1423-1430.

https://doi.org/10.1016/j.pec.2020.11.018

26. Yu M, Kang KJ. Effectiveness of a role-play simulation program involving the sbar technique: A quasi-experimental study. Nurse Education Today. 2017;53:41-47. https://doi.org/10.1016/j.nedt.2017.01.002

27. Labrague LJ, McEnroe-Petitte DM, Fronda DC, Obeidat AA. Interprofessional simulation in undergraduate nursing program: An integrative review. Nurse Education Today. 2018;67:46-55. https://doi.org/10.1016/j.nedt.2018.05.001

28. Oates M, Davidson M. A critical appraisal of instruments to measure outcomes of interprofessional education. Medical Education. 2015;49(4):386-398. https://doi.org/10.1111/medu.12681 


\section{Appendix 1. Citations for Studies Included in this Study}

1. Van Schaik SM, Plant J, Diane S, Tsang L, O'Sullivan P. Interprofessional team training in pediatric resuscitation: A low-cost, in situ simulation program that enhances self-efficacy among participants. Clinical Pediatrics. 2011;50(9):807-815. https://doi.org/10.1177/0009922811405518

2. Atamanyuk I, Ghez O, Saeed I, Lane M, Hall J, Jackson T, et al. Impact of an open-chest extracorporeal membrane oxygenation model for in situ simulated team training: A pilot study. Interactive Cardiovascular and Thoracic Surgery. 2014;18(1):17-20.

https://doi.org/10.1093/icvts/ivt437

3. Luctkar-Flude M, Baker C, Medves J, Tsai E, Rivard L, Goyer MC, et al. Evaluating an interprofessional pediatrics educational module using simulation. Clinical Simulation in Nursing. 2013;9(5): e163-e169. https://doi.org/10.1016/j.ecns.2011.11.008

4. Kotsakis A, Mercer K, Mohseni-Bod H, Gaiteiro R, Agbeko R. The development and implementation of an inter-professional simulation based pediatric acute care curriculum for ward health care providers. Journal of Interprofessional Care. 2015;29(4):392-394. https://doi.org/10.3109/13561820.2014.984018

5. Auerbach M, Whitfill T, Gawel M, Kessler D, Walsh B, Gangadharan S, et al. Differences in the quality of pediatric resuscitative care across a spectrum of emergency departments. JAMA Pediatrics. 2016;170(10):987-994.

https://doi.org/10.1001/jamapediatrics.2016.1550

6. Kessler DO, Walsh B, Whitfill T, Dudas RA, Gangadharan S, Gawel $\mathrm{M}$, et al. Disparities in adherence to pediatric sepsis guidelines across a spectrum of emergency departments: A multicenter, crosssectional observational in situ simulation study. The Journal of Emergency Medicine. 2016;50(3):403-415.

https://doi.org/10.1016/j.jemermed.2015.08.004

7. Gilfoyle E, Koot DA, Annear JC, Bhanji F, Cheng A, Duff JP, et al. Improved clinical performance and teamwork of pediatric interprofessional resuscitation teams with a simulation-based educational intervention. Pediatric Critical Care Medicine. 2017;18(2): e62-e69. https://doi.org/10.1097/PCC.0000000000001025

8. Hewett EK, Nagler J, Monuteaux MC, Morin M, Devine M, Carestia $\mathrm{M}$, et al. A hazardous materials educational curriculum improves pediatric emergency department staff skills. AEM Education and Training. 2017;2(1):40-47. https://doi.org/10.1002/aet2.10077

9. Auerbach M, Brown L, Whitfill T, Baird J, Abulebda K, Bhatnagar $\mathrm{A}$, et al. Adherence to pediatric cardiac arrest guidelines across a spectrum of fifty emergency departments: A prospective, in situ, simulation-based study. Academic Emergency Medicine. 2018;25 (12):1396-1408. https://doi.org/10.1111/acem.13564

10. Couto TB, Barreto JKS, Marcon FC, Mafra ACCN, Accorsi TAD. Detecting latent safety threats in an interprofessional training that combines in situ simulation with task training in an emergency department. Advances in Simulation. 2018;3:23.

https://doi.org/10.1186/s41077-018-0083-4

11. Gangadharan S, Tiyyagura G, Gawel M, Walsh BM, Brown LL, Lavoie $\mathrm{M}$, et al. A grounded theory qualitative analysis of interprofessional providers' perceptions on caring for critically Ill infants and children in pediatric and general emergency departments. Pediatric Emergency Care. 2018;34(8):578-583. https://doi.org/10.1097/PEC.0000000000000906

12. Goldman MP, Wong AH, Bhatnagar A, Emerson BL, Brown LL, Auerbach MA. Providers' perceptions of caring for pediatric patients in community hospital emergency departments: A mixed-methods analysis. Academic Emergency Medicine. 2018;25(12):1385-1395. https://doi.org/10.1111/acem.13509

13. Abu-Sultaneh S, Whitfill T, Rowan CM, Friedman ML, Pearson KJ, Berrens ZJ, et al. Improving simulated pediatric airway management in community emergency departments using a collaborative program with a pediatric academic medical center. Respiratory Care. 2019;64(9):1073-1081. https://doi.org/10.4187/ respcare.06750

14. Figueroa MI, Sepanski R, Goldberg SP, Shah S. Improving teamwork, confidence, and collaboration among members of a pediatric cardiovascular intensive care unit multidisciplinary team using simulation-based team training. Pediatric Cardiology. 2013;34 (3):612-619. https://doi.org/10.1007/s00246-012-0506-2

15. Hartford E, Thomas A, Keilman A, Uspal N, Stone K, Reid J, et al. pediatric toxidrome simulation curriculum: Bupropion overdose. MedEdPORTAL. 2019;15:10846. https://doi.org/10.15766/mep_2374-8265.10846

16. Jordan KS, Steelman SH, Leary M, Varela-Gonzalez L, Lassiter SL, Montminy L, et al. Pediatric sexual abuse: An interprofessional approach to optimizing emergency care. Journal of Forensic Nursing. 2019;15(1):15-25. https://doi.org/10.1097/JFN.0000000000000232

17. So M, Dziuban EJ, Franks JL, Cobham-Owens K, Schonfeld DJ, Gardner AH, et al. Extending the reach of pediatric emergency preparedness: A virtual tabletop exercise targeting children's needs. Public Health Reports. 2019;134(4):344-353. https://doi.org/10.1177/0033354919849880

18. Diaz MCG, Dawson K. Impact of simulation-based closed-loop communication training on medical errors in a pediatric emergency department. American Journal of Medical Quality. 2020;35(6): 474-478. https://doi.org/10.1177/1062860620912480

19. Garrow AL, Zaveri P, Yuknis M, Abulebda K, Auerbach M, Thomas EM. Using simulation to measure and improve pediatric primary care offices emergency readiness. Simulation in Healthcare. 2020;15(3):172-192. https://doi.org/10.1097/SIH.0000000000000472

20. Shah SJ, Cusumano C, Ahmed S, Ma A, Jafri FN, Yang CJ. In situ simulation to assess pediatric tracheostomy care safety: A novel 
multicenter quality improvement program. Otolaryngology-Head and Neck Surgery. 2020;163(2):250-258.

https://doi.org/10.1177/0194599820923659

21. Wiesbrock, J, Andresen P, Brough M. Simulation to support stand- ardization of delivery room management of the very low birthweight infant. Advances in Neonatal Care. 2020.

https://doi.org/10.1097/ANC.0000000000000768 